\title{
Efficiency Dynamics of Initial Public Offerings Using Data Envelopment Analysis and Malmquist Productivity Index Approach
}

\author{
Muhammad Khalid Sohail ${ }^{1}$, Muhammad S. Anjum² \\ Capital University of Science and Technology \\ Islamabad Expressway, Kahuta Road, Zone-V, Islamabad, Pakistan \\ E-mail.'halid_sohail@comsats.edu.pk, ${ }^{1}$ mkhalids33@live.com, ${ }^{2}$ anjum@cust.edu.pk \\ cross $^{\text {ref }}$ http://dx.doi.org/10.5755/j01.ee.27.2.10062
}

\begin{abstract}
This study examined the efficiency and productivity growth of Initial Public Offerings (IPOs) of firms listed on Karachi Stock Exchange (KSE) Pakistan from 2000 to 2012 by using Data Envelopment Analysis (DEA) and Malmquist Productivity Index (MPI) in three stages. The analysis and comparison of the efficiency and productivity growth of IPOs on sectoral basis in the pre and post period of IPOs was also investigated. This is first ever study to measure the pre IPO efficiency across the globe in the field of IPOs. The overall efficiency scores of IPO firms are dismal as the percentage of optimum level of IPO firm's remained between 5 to 20 percent in all three stages in pre and post IPOs. In the analysis of broader categories of sectors: private, state-owned enterprises (SOEs), manufacturing, financial and other services sectors, the results of DEA model in three stages suggest that all the sectors were neither found to be Constant Returns to Scale (CRS) efficient nor Variable Returns to Scale (VRS) efficient in pre and post IPOs. Even the efficiency scores decreased in post IPO after one year. However, in detail sector-wise analysis, only Oil and Gas sector showed optimal level under VRS in stage 2. Also, SOEs showed slightly better efficiency than private IPO firms. On average, declining trends in total productivity growth of IPOs after the three years period were observed. The overall results suggest that, after acquiring additional resources, IPO firms did not show improved efficiency level and productivity growth after the period of three years of IPOs.
\end{abstract}

Keywords: Initial Public Offerings, Data Envelopment Analysis, Sate Owned Enterprises, Private, Karachi Stock Exchange

\section{Introduction}

The data envelopment analysis (DEA) is widely used to measure the performance and productivity of different sectors like banking, health care and mutual funds etc. There are numerous studies with regard to application of DEA like Nunamaker (1985), Vahid \& Sowlati (2007), Kong and Tongzon (2006), Wang (2006), Sufian \& Kamarudin (2014), and Ataullah \& Le (2006), Carrico et al. (1997), Edirisinghe and Zhang (2008), Miliotis (1992), Andries et al. (2013), Berger and Mester (2003) and Banker et al. (1984).

However, in case of initial public offerings (IPOs), application of DEA approach is not common. Greg (2006) was the first researcher who used DEA approach in initial public offering and concluded that an efficient IPO falls in low price range of all the periods of sample. Globally, there are very few studies (Yan and Zehong (2013), Chen (2012), Alanazi (2010), Luo \& Yao (2009) and Greg (2006)) that used DEA approach to measure the performance of IPOs.

Besides, the performance of State Owned Enterprises (SOEs) also remains the main focus of researchers. Privatization aims to improve the efficiency and profitability of non-performing SOEs by shifting their resources to private sector.

In Pakistan, the privatization of SOEs started in 1990's and became an important instrument of economic policy. From 1990's to mid of 2000 several SOEs were shifted to private sector including banks, cement, textile, telecommunication, fertilizers and energy sectors.
Megginson and Netter (2001) have reviewed the literature about SOEs and privatization and concluded the main goals were to reduce budget deficits, develop financial markets and to increase efficiency. Several studies have focused on long run performance of IPOs using different methods such as CAR (cumulative abnormal returns), BAHR (Buy and hold abnormal returns) and asset pricing models. However, all these methods remained controversial due to statistical and econometric problems as discussed in Barber and Lyon (1997), Fama French (1995), Chen et al. (2002), Brav (2000) and Fama French (1993) studies.

Initially, Barber and Lyon (1997) raised the issue and favored BHARs over CARs by arguing the return's pattern of BHARs observe the investment strategy of investor's return. On the other hand Fama French (1995) favored the CARs over BHARs due to the linearity pattern of averages. In asset pricing models, CAPM is criticized by Chen et al. (2002) by favoring Fama French 3-factor model. In contrast, Brav (2000) criticized Fama French (1993) model due to not holding the assumptions of independency and normality.

Despite the controversy of various methods, investors usually observed underperformance of IPOs in the long run as reported by Welch (1989), Ritter (1991), Brau (2012), Jain \& Kini (1994), Loughran and Ritter (1995) and Sohail \& Nasr (2007).

In order to tackle the statistical and econometric problems, DEA and Malmquist methodology has been used in this study to observe the efficiency of IPOs. DEA is a preferred technique as it does not require the 
assumptions of regression analysis as it focuses on individual observations rather than on population. Further, it compares firm performance on the basis of best-practice frontier rather than on central-tendency properties by utilization of inputs (independent variables) to produce outputs (dependent variables).

This study has used the DEA approach to analyze the efficiency of IPOs in pre and post window and its contribution lies in determining whether public listing helps increase efficiency of new firms and especially the SOEs. On this aspect, this study is a pioneering effort as no earlier study is available on finding the pre IPO efficiency of firms in Pakistan or elsewhere.

\section{Literature Review}

There are numerous studies with regard to application of DEA and total factor productivity (TFP). Nunamaker (1985) measured the efficiency of nonprofit organizations by using DEA approach. Vahid \& Sowlati (2007) applied DEA to measure the efficiency of the Canadian's firms, Kong and Tongzon (2006) used DEA approach to estimate total factor productivity growth of Singapore's firms. Wang (2006) used DEA and Balanced Score Card (BSC) approach to analyze and evaluate the corporate performance efficiency. Ataullah \& Le, (2006) used DEA technique for efficiency measurement of the Indian Banking Industry.

By using input Charnes, Cooper and Rhodes (CCR) model in conjunction with Zhoo (2003) model, Greg (2006) concluded that an efficient IPO falls in low price range of all periods of sample and gave a better avenue to select an IPO.

Luo \& Yao (2009) analyzed pre-post IPOs performance of banking sector by using DEA approach and observed 10 percent efficiency in Chinese banks after IPOs period. They further reported that the previously inefficient state owned banks reduced the gap of efficiency with the joint stock commercial banks of China. In contrast to Luo \& Yao, Alanazi (2010) reported the significant decline of Saudi IPOs after listing using Malmquist productivity and efficiency indices under DEA approach.

Luo and Yao (2009) also reported the mean efficiency of Chinese commercial banks to 0.7 under the input CCR model, whereas, the efficiency of 10 commercial banks improved after going to IPOs. Under VRS model they reported 6 percent increased efficiency as compared to CCR model. They reported that, for pure technical efficiency, SOEs outperformed as compared to all other Chinese banks.

Yan and Zehong (2013) selected 51 SOEs in China and presented their efficiency analysis after going public in 2010. They found that efficiency did not increase in these IPOs after going public. Contrary to the finding of Yan and Zehong (2013), Chen (2012) showed that the technical efficiency of 21 banks increased 6.22 percent while the improvement in technological changes was up by 16 percent from 2006 to 2011.

The deficient in the existing literature is identified to measure the efficiency of IPOs and specially the sector-wise efficiency in pre and post IPOs event window.

\section{Research Methodology}

Farrell (1957), first time introduced this approach. This methodology was extended by Charnes, Cooper and Rhodes (1978) to introduce CCR model, later on extended by Banker, Charnes and Cooper (1984) to introduce BCC model. The sample firms comprised of 83 IPOs listed during the period of 2000 to 2012 . However, to observe the efficiency for three years period, IPOs not covering three years were eliminated and IPO firms were reduced to 60 .

The efficiency score (ES) for each IPO firm in the presence of multiple input and output factors is defined as:

$$
\begin{aligned}
& \text { Maximize ES }=\frac{\text { WtdSumOfOutput }}{\text { WtdSumOfIntput }} \\
& \text { S.T: } \quad E S=\frac{\text { WtdSumOfOutput }}{\text { WtdSumOfInput }} \leq 1 \text { for } j=1 \text { to N }
\end{aligned}
$$

$\mathrm{F}$ or mathematical formulation it is assumed that there are $\mathrm{k}$ number of IPOs each with $\mathrm{N}$ number of inputs to produce $\mathrm{M}$ outputs. The relative efficiency score of an IPO firm was obtained by using the following model proposed by Charnes et al. (1978).

$$
T E=\sum_{i=1}^{m} u_{i} Y_{i k} / \sum_{j=1}^{n} v_{j} x_{j k}
$$

Where, $\mathrm{y}_{i k}=$ Amount of output $i$ produced by the firm $k, \mathrm{x}_{j k}=$ Amount of input $j$ utilized by firm $s, \mathrm{u}_{i}=$ Weight given to output $i, \mathrm{v}_{j}=$ Weight given to input $j$. The firms maximize the efficiency ratio $\mathrm{TE}_{\mathrm{k}}$, subject to:

$$
\sum_{i=1}^{m} u_{i} Y_{i k} / \sum_{j=1}^{n} v_{j} x_{j k} \leq 1
$$

In the above algebraic equation the efficiency measure of an IPO firm with the two important constraints that it cannot exceed 1, while the weights of input / output are positive. The overall objective is to improve the efficiency by selecting the optimal weights that can be selected using linear programming specified by Coelli (1998), Worthington (1999) and Shiu (2002).

$$
\begin{gathered}
\text { Max. TE } \begin{aligned}
& \text { S.T. } \\
& \sum_{i=1}^{m} u_{i} y_{i r}-x_{j r}+w \leq 0, r \\
= & 1, \ldots, k
\end{aligned} \\
v_{j} x_{j r}-\sum_{i=1}^{n} u_{i} x_{j k}, \quad u_{j} \& v_{j} \geq 0
\end{gathered}
$$

To obtain the minimized inputs, input oriented linear method was used as suggested by Banker and Thrall (1992), Coelli (1998) and Shiu (2002).

$$
\begin{gathered}
\text { Max. TE } \begin{aligned}
\text { S.T. } & \sum_{i=1}^{m} u_{i} y_{i r}-y_{j r}+w \geq 0, r \\
& =1, \ldots, k
\end{aligned} \\
x_{j r}-\sum_{i=1}^{n} u_{i} x_{j k} \geq 0, \quad u_{j} \& v_{j} \geq 0
\end{gathered}
$$

The technical efficiency involves the conversion of physical inputs into outputs on best practice basis. An IPO 
firm operating at best practice is said to be 100 percent technically efficient firm.

The CCR model assumed that all units were operated under CRS while BCC model assumed VRS effect. Here in this study BCC and CCR both models were used to measure the pre-post IPOs efficiency. The analysis of scale efficiency which is the ratio of CRS to VRS was also conducted. The IPO firm is said to be scale efficient if the ratio is one.

To test the statistical significance of scale efficiencies, the $t$ statistic was employed. For, input and output, this study used the two-phase methodology, originally devised by Zhu (2000) and used by Chen, Cook and Zhu (2009).

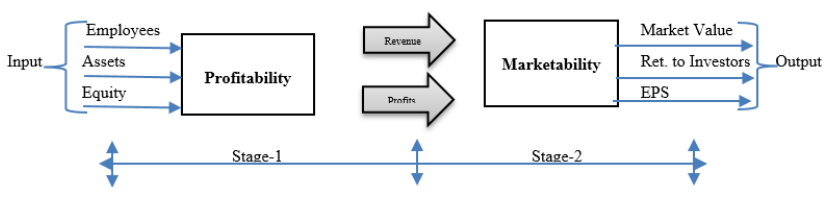

Figure 1. Input-Output Matrix

The selection of input and output variables is highly debatable. Jenkins and Anderson (2003) devised the statistical approach regarding the number of input and output variables. Edirisinghe and Zhang (2010) also devised a mechanism for selection of variables as inputs and outputs under the endogenous and exogenous aspect. Dyson et al. (2001) suggested that the sample size should be twice the multiplication of the number of inputs and outputs. Joro and Viitala (2004) concluded that all inputs and outputs were not equally appropriate. On the other hand most of the studies are reconciling with these input and output variables under the umbrella of production variables like labor capital etc. The methodology of Feroz (2003) and Wang (2006) is based on conversion of financial performance indicators into technical efficiency by means of input output variables. In this study, we followed the aforementioned methodology in conjunction with Zhu (2000) and Chen et al (2009).

A time series analysis in DEA in the form of Malmquist Productivity Index (MPI) is used to observe overtime efficiency of IPOs. It was initiated by Caves et al. (1982) and got popularized by the work of Fare et al. (1994). It is the product of two terms: the "catching-up" and the "frontier shift". The first one refers to improving efficiency overtime, while the latter deals with change in the efficient frontier between the two time periods as discussed below.

$$
m_{0}\left(y_{z}, x_{z}, y_{t} x_{t}\right)=\sqrt{\frac{d_{0}^{s}\left(y_{t}, x_{t}\right)}{d_{0}^{S}\left(y_{z}, x_{z}\right)}} \times \frac{d_{0}^{t}\left(y_{t}, x_{t}\right)}{d_{0}^{t}\left(y_{z}, x_{z}\right)}
$$

\section{Analysis and Discussion}

The main objective of this section is to provide analysis and comparison of the efficiency of IPOs in pre and post IPO's event.

\section{Descriptive Analysis}

The descriptive statistics include average, median, variability and range of variables minimum to maximum. In pre-IPOs descriptive statistics, for input variables, the mean equity, the mean assets and the mean number of employees of these IPOs remained at Rs. 4413.395 million, Rs. 32353.944 million and 1296 respectively. The mean revenue and the mean profit after taxes remain at Rs. 4429.163 million and Rs. 986.152 million respectively.

For output variables, the mean market value, Earning Per Share (EPS) and return to investors remain at Rs. 11970.864 million, Rs. 4.084 and Rs. 432.302 million respectively. The variability in equity was observed to be 11528.952 million and ranged between 9.460 and 70671.493 million. The number of employees ranged from 9 to 15000 .

Compared with pre IPO, the variables used in post IPO analysis for three year period showed an increasing trend in all measures of descriptive statistics.

\section{Pre IPO efficiency}

The DEA was used in this analysis to measure the efficiency of IPOs before going to public in three ways. The input oriented DEA was measured as CRS, VRS and Scale efficiencies.

The efficiency scores of stage 1 (profitability) indicated that only $6.67 \%$ IPO firms were CRS efficient and located on efficient frontier. These IPO firms produced output at optimal level .i.e. for given level of inputs; total assets, total equity and number of employees produced maximum level of output i.e. total revenue and profit after taxes. It implies that these IPO firms were operating at $100 \%$ efficiency level before going public. Further, 5 percent IPO firms showed relatively good efficiency scores between 0.8 and 1 . On the other hand, 5 percent of IPO firms showed efficiency scores between 0.6 and $0.8,11.67$ percent between 0.4 and $0.6,15$ percent between 0.2 and 0.4 while 56.67 percent were below 0.2 . On average, the efficiency score of these IPO firms was observed to be 0.294 . The reasons for such dismal efficiency score might be due to the new firms going to public as new firms incur losses initially and then become profitable after some years of operation. The efficiency can be improved either by reducing the input level or improving the output level.

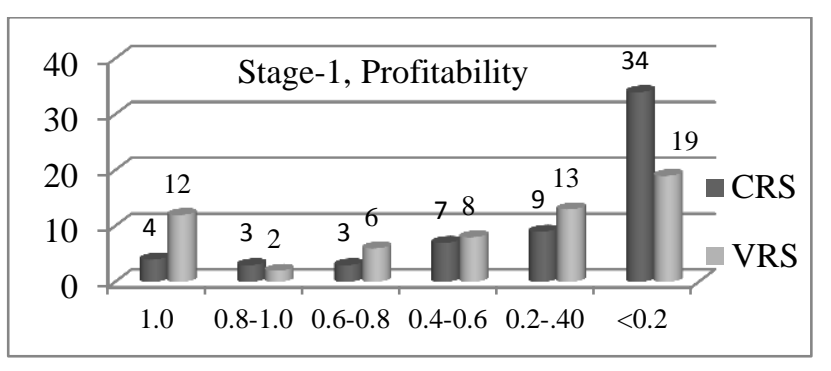

Figure 2. CRS and VRS of pre-IPOs (Stage-1, Profitability)

The average efficiency score with regard to VRS was observed to be 0.475 , higher than the average efficiency score by CRS. In VRS analysis, only 20 percent IPO firms were observed to be VRS efficient and located on efficient frontier. These IPO firms produced output at optimal level. Further, 3.33 percent IPO firms also showed relatively good efficiency score between 0.8 and 1 . However, more than 66.67 percent showed efficiency score less than 0.6 (Figure 2). 
The efficiency scores of stage 2 (marketability) portrayed that only 8.34 percent of IPO firms were CRS efficient and located on the efficient frontier. These IPO firms produced output at optimal level .i.e. for given level of inputs, total revenue and profit after tax produced maximum level of output.

On the other hand, 91.67 percent of IPO firms showed efficiency scores less than 0.6. On average the efficiency score of these IPO firms was observed to be 0.194 . The average efficiency score with regard to VRS was observed to be 0.412 , higher than the average efficiency score by CRS as in case of stage-1. In VRS analysis, only 21.67 percent of IPO firms were observed to be VRS efficient and located on the efficient frontier. These IPO firms produced output at optimal level. Further, 6.67 percent of IPO firms also showed relatively good efficiency score between 0.8 and 1. However, more than 71.67 percent showed efficiency score less than 0.6 (Figure 3).

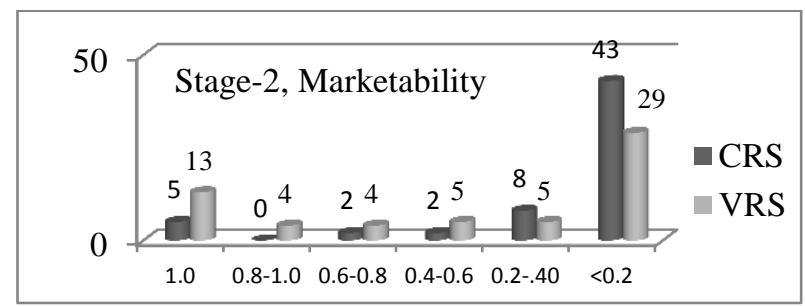

Figure 3. CRS and VRS of pre-IPOs (Stage-2, Marketability)

The efficiency scores of stage 3 (overall), revealed that 13.33 percent of IPO firms were CRS efficient and located on the efficient frontier. These IPO firms produced output at optimal level using inputs as number of employees, assets and equity and produced maximum level of output i.e. earnings per share, return to investors and total market value. Conversely, 81.67 percent of IPO firms showed efficiency scores less than 0.8. On average the efficiency score of these firms was observed to be 0.43 , which was higher than average score in stage 1 and 2.

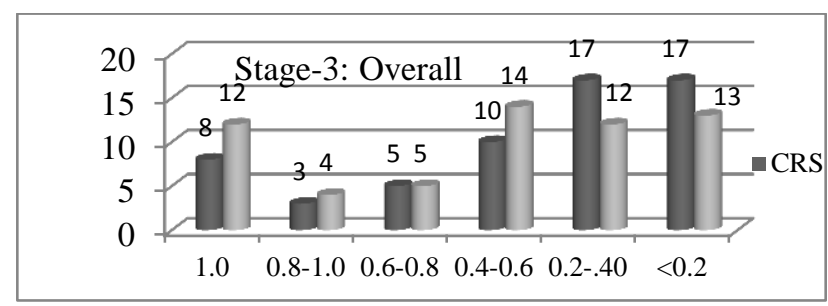

Figure 4. CRS and VRS of pre-IPOs (Stage-3, overall)

The average VRS efficiency in stage 3 is observed to be 0.516 , higher than the average efficiency score by CRS as in case of stage-1 and 2. The VRS analysis shows that only $20 \%$ IPO firms are VRS efficient; while more than $73.33 \%$ showed efficiency score less than 0.6. These results of efficiency scores are displayed in the Figure 4.

To test the statistical significance of scale efficiencies in all the three stages, the t statistic show the scale efficiencies highly significant at $1 \%$ level implying the average score of all IPO sample firms to be less than 1.This indicates severe scale inefficiencies in IPO firms before going public.
The results of pre IPO efficient firms are displayed in Table 1. In stage 1 and 3, 12 IPO firms showed $100 \%$ efficiency in all the three efficiency measures of CRS, VRS and Scales. These IPO firms increased to 28 in stage 2 for these efficiency measures of CRS, VRS and Scales. IPO firm 3 was efficient in stage 2 and stage 3 for CRS, VRS and Scales. Whereas, the IPO firm 55 was the only firm that remained efficient in all stages for CRS, VRS and Scale measures.

Table 1

Pre-IPO Efficient Firms

\begin{tabular}{|c|c|c|c|c|c|c|c|c|c|c|c|c|c|c|c|c|c|c|}
\hline \multirow{2}{*}{ IPO } & \multicolumn{3}{|c|}{ S-1 } & \multicolumn{3}{|c|}{ S-2 } & \multicolumn{3}{|c|}{ S-3 } & \multirow{2}{*}{ IPO } & \multicolumn{2}{|c|}{ S-1 } & \multicolumn{3}{|c|}{ S-2 } & \multicolumn{3}{|c|}{$S-3$} \\
\hline & C & $\mathbf{V}$ & $\mathbf{S}$ & C & $\mathbf{V}$ & $\mathbf{S}$ & C & $\mathbf{V}$ & $\mathbf{S}$ & & \begin{tabular}{l|l}
$\mathbf{C}$ & $\mathbf{V}$
\end{tabular} & $\mathbf{S}$ & $\mathbf{C}$ & $\mathbf{V}$ & $\mathbf{S}$ & C & V & $\mathbf{S}$ \\
\hline 2 & & & & & & * & & & & 43 & & & & & $*$ & & & \\
\hline 3 & & & & $*$ & $*$ & * & $*$ & $*$ & $*$ & 44 & & & & $*$ & & & $*$ & \\
\hline 6 & & $*$ & & & & & & & & 48 & $*$ & & & & & & & \\
\hline 7 & & & & & & * & & & & 53 & & & & & * & & & \\
\hline 8 & & & & & $*$ & & & & & $55 *$ & $* \quad *$ & $*$ & $*$ & $*$ & * & $*$ & $*$ & $*$ \\
\hline 9 & & & & & & * & & & & 56 & & & & & $*$ & & & \\
\hline 11 & & & & & & * & & & & 58 & & & & & $*$ & & & \\
\hline 15 & & $*$ & & & $*$ & & & * & & 59 & $*$ & & & & & & & \\
\hline 18 & & & & & & * & & & & 62 & $*$ & & & $*$ & & & $*$ & \\
\hline 26 & & $*$ & & & & & & * & & 64 & & & & $*$ & & & & \\
\hline 28 & & $*$ & & & & & * * & $*$ & $*$ & 65 & & & $*$ & $*$ & * & & & \\
\hline 29 & & & & & & * & & & & 66 & & & & & $*$ & & & \\
\hline 30 & & & & $*$ & & & * * & $*$ & $*$ & 67 & $*$ & & & & $*$ & $*$ & $*$ & $*$ \\
\hline 35 & $*$ & $*$ & $*$ & & $*$ & & $*$ & * & $*$ & 69 & & & & & & $*$ & & $*$ \\
\hline 36 & $*$ & $*$ & $*$ & & $*$ & & $* *$ & $*$ & $*$ & 70 & & & & & $*$ & & & \\
\hline 39 & $*$ & $*$ & $*$ & & & * & & & & 75 & & & & $*$ & & & & \\
\hline 41 & & & & & & $*$ & & & & 76 & & & $*$ & $*$ & * & & & \\
\hline
\end{tabular}

\section{Sector-wise Analysis}

IPO firms were divided into broader categories: manufacturing, financial, other sectors, detailed industry wise, private and SOEs (Table 2). The DEA results of stage 1 indicated that CRS scores of manufacturing sector were higher than those of financial and other sectors. However, in VRS, manufacturing sector was not dominant as compared with financial and other sectors. In stage 2, both CRS and VRS analysis, financial and other sectors showed better efficiency than manufacturing sector. Similarly, the results of stage 3 were in accordance with stage 2 results except that other sectors score exceeded 0.50 under VRS. All these results suggest that none of the sectors was CRS efficient or VRS efficient in all three stages.

I n sector-wise analysis, the oil and gas sector showed better performance than other sectors according to CRS efficiency score in stage 1. The sectors including Support Services, Fixed Line Telecommunication, General Industrials, Industrial Transportation, Personal Goods, Automobile and Parts, showed very low $(<0.2)$ efficiency scores under CRS.

Other sectors including Banks, Construction and Materials, Equity Investment Instruments, Chemicals, Financial Services, Electricity and Media showed efficiency scores between 0.2 and 0.4. The Real Estate Investment \& Services, Industrial Metals \& Mining and 
Software \& Computer Services sectors showed better efficiency scores i.e., between 0.4 and 0.6.

Table 2

Detailed Sector-wise Analysis

\begin{tabular}{|c|c|c|c|c|c|c|c|c|c|}
\hline \multirow{2}{*}{ Category } & \multicolumn{3}{|c|}{ Stage-1 } & \multicolumn{3}{|c|}{ Stage-2 } & \multicolumn{3}{|c|}{ Stage-3 } \\
\hline & CRS & VRS & Scale & CRS & VRS & Scale & CRS & VRS & Scale \\
\hline \multicolumn{10}{|c|}{ Panel-A: Sector-wise Analysis } \\
\hline Financial Sector & 0.2583 & 0.5764 & 0.4711 & 0.1982 & 0.4121 & 0.6218 & 0.4089 & 0.4979 & 0.7893 \\
\hline Manufacturing Sector & 0.2886 & 0.2777 & 0.2739 & 0.1662 & 0.3177 & 0.3576 & 0.2120 & 0.2422 & 0.1552 \\
\hline Other Sectors & 0.2581 & 0.3553 & 0.5107 & 0.1999 & 0.4703 & 0.5785 & 0.4979 & 0.5720 & 0.8456 \\
\hline \multicolumn{10}{|c|}{ Panel-B: Industry-wise Analysis } \\
\hline Automobile And Parts & 0.1670 & 0.2630 & 0.6330 & 0.0150 & 0.0150 & 0.9990 & 0.1120 & 0.1750 & 0.6390 \\
\hline Banks & 0.2088 & 0.4647 & 0.5744 & 0.0827 & 0.4760 & 0.2503 & 0.2461 & 0.4233 & 0.6837 \\
\hline Chemicals & 0.3306 & 0.4383 & 0.6006 & 0.4150 & 0.5694 & 0.6737 & 0.5404 & 0.5754 & 0.9051 \\
\hline Construction And Materials & 0.2090 & 0.2273 & 0.9068 & 0.0803 & 0.0803 & 1.0000 & 0.2135 & 0.2365 & 0.9063 \\
\hline Electricity & 0.3593 & 0.4430 & 0.5127 & 0.4833 & 1.0000 & 0.4833 & 0.7073 & 0.7370 & 0.9540 \\
\hline Equity Investment Instruments & 0.2091 & 0.6556 & 0.3084 & 0.1606 & 0.1673 & 0.8650 & 0.4819 & 0.6867 & 0.6940 \\
\hline Financial Services & 0.3460 & 0.6267 & 0.4943 & 0.2030 & 0.4384 & 0.6801 & 0.6311 & 0.7031 & 0.8440 \\
\hline Fixed Line Telecommunication & 0.0280 & 0.0660 & 0.4240 & 0.0370 & 0.0400 & 0.9130 & 0.1310 & 0.1360 & 0.9670 \\
\hline General Industrials & 0.1110 & 0.3010 & 0.3680 & 0.1860 & 0.1860 & 1.0000 & 0.4070 & 0.4580 & 0.8900 \\
\hline Industrial Metals And Mining & 0.4860 & 0.5985 & 0.4870 & 0.0185 & 0.0660 & 0.4435 & 0.5270 & 0.5435 & 0.9690 \\
\hline Industrial Transportation & 0.1150 & 0.1240 & 0.9340 & 0.0270 & 0.0270 & 0.9990 & 0.0750 & 0.2390 & 0.3130 \\
\hline Media & 0.3713 & 0.4743 & 0.4867 & 0.1433 & 0.1537 & 0.6523 & 0.2763 & 0.3123 & 0.8627 \\
\hline Oil And Gas Producers & 0.6630 & 0.7678 & 0.6630 & 0.3210 & 0.9970 & 0.3215 & 0.6488 & 0.7805 & 0.8600 \\
\hline Personal Goods & 0.1550 & 0.1780 & 0.8690 & 0.1288 & 0.1288 & 0.9996 & 0.1186 & 0.1328 & 0.8554 \\
\hline Real Estate Invest. \& Services & 0.4340 & 0.4640 & 0.9360 & 0.2260 & 0.9320 & 0.2430 & 0.5200 & 0.5220 & 0.9970 \\
\hline Software \& Computer Services & 0.5960 & 0.7030 & 0.8470 & 0.1550 & 1.0000 & 0.1550 & 0.9770 & 1.0000 & 0.9770 \\
\hline Support Services & 0.0010 & 0.2800 & 0.0020 & 0.2290 & 0.5770 & 0.3980 & 0.4880 & 0.5060 & 0.9640 \\
\hline \multicolumn{10}{|c|}{ Panel-C: Private V/S State owned Enterprise } \\
\hline Private Enterprises & 0.2896 & 0.4917 & 0.5498 & 0.1987 & 0.3790 & 0.6527 & 0.4235 & 0.5160 & 0.8108 \\
\hline Sate Owned Enterprises & 0.3143 & 0.4007 & 0.7073 & 0.1733 & 0.5583 & 0.5862 & 0.4596 & 0.5175 & 0.8812 \\
\hline
\end{tabular}

The VRS efficiency scores were observed to be higher than the efficiency scores of CRS in stage 1. Like CRS analysis, for VRS efficiency score in stage 1, Oil and Gas sector showed better performance than all other sectors. For marketability analysis of stage 2, none of the sectors met the efficiency score of 0.5 under CRS. However, two sectors (Electricity, Software \& Computer Services) showed their efficiency score at optimal level under VRS. Besides, the Oil \& Gas sector was also found to be very close to efficient frontier. Similarly the Real Estate Investment \& Services sector showed relatively good efficiency score of 0.932. All other sectors except Chemicals and Support Services showed efficiency scores of less than 0.5 under VRS analysis of stage 2 .

In the overall analysis of stage 3 , the efficiency scores were found to be higher than the efficiency scores in stage 1 and 2. Only Software \& Computer Services sector showed efficiency score near to optimal level under CRS. In six sectors; Real Estate Investment \& Services, Industrial Metals \& Mining, Chemicals, Financial Services, Oil \& Gas Producers and Electricity, the efficiency score remained between 0.5 and 0.7 . For all other sectors, the efficiency scores were less than 0.5. In VRS analysis, the Oil \& Gas Producers, Electricity and Financial Services sectors showed relatively good efficiency scores. The efficiency score in stage 3 under VRS for Support Services, Real Estate, Investment \& Services and Industrial Metals \& Mining remained between 0.5 and 0.7 .

The efficiency scores of private and SOEs are displayed in panel $\mathrm{C}$ of Table 2 . In stage 1 , both private and SOEs did not meet the efficiency score of 0.5 under CRS; however, under VRS private firms approached efficiency score to 0.4917 . In stage 2 , the efficiency score only reached 0.2 in CRS measure. However, in stage 2, under VRS, SOEs showed better efficiency score (0.5583) as compared to the private sector. In stage 3, although, SOEs showed marginally greater efficiency than private under CRS but it was less than 0.5. On the other hand, interestingly, the efficiency scores were observed to be same both in CRS and VRS analysis.

One probable reason for non-performance of private firms in comparison to SOEs may be that most of the private firms were newer than SOEs. The other reason might be due to lesser number (18 percent) of IPO firms in SOEs category showing better efficiency while 82 percent of IPO firms were related to private.

To sum up, the overall efficiency scores of IPO firms remained dismal as the percentage of optimum level of IPO firms remained between 5 to 20 percent for all three stages in pre IPO. In the analysis of broader categories of sectors (private, SOEs, manufacturing, financial, other services), the three-stage results of DEA model indicated that neither of the sector was CRS efficient nor VRS efficient before going public. However, in detail sectorwise analysis, only the Oil and Gas sector showed optimal level under VRS in stage 2.

\section{Post IPO efficiency, after one year}

The post efficiency, after one year, scores of all three stages showed that, in stage 1, only 6.67 percent of IPO firms were both CRS as well as VRS efficient. In stage 2, only 5 percent of IPO firms were CRS efficient while 16.67 percent were VRS efficient. In the $3^{\text {rd }}$ stage, the score of efficient firms increased to 13.3 percent while the 
same efficiency score under VRS was observed as in stage 1 and 2. These IPO firms produced output at optimal level i.e., these firms were operating at 100 percent efficiency level one year after going public.

The results further suggest that 85 percent of IPO firms in stage $1,93.33$ percent in stage 2 and 83.33 percent in stage 3, showed efficiency score less than 0.2 under CRS. Similarly, 70, 75 and 68.33 percent of IPO firms in stage 1, 2 and 3, respectively, showed efficiency less than 0.2 scores under VRS. In other words, the results indicate dismal performance of IPOs firms after one year of initial public offerings. This shows that after acquiring further resources of equity, assets and addition of employees, IPO firms did not improve their efficiency level. The scores of CRS remain, on average, at 0.273 for stage $1,0.2$ for stage 2 and 0.355 for stage 3 . The overall efficiency scores under CRS decrease to 7.14 percent in stage 1 and 17.44 percent in stage 3 . However, in stage 2, the efficiency scores only increased from 0.194 to 0.2 . In variable returns to scale analysis, the average VRS scores remained at 0.476 for stage $1,0.341$ for stage 2 and 0.491 for stage 3 . Similarly, on average, the decreasing pattern of efficiency scores was also observed in VRS in stage 1 and stage 3. Moreover, decreasing efficiency scores were witnessed in Scale efficiencies for all the three stages as well.

In CRS analysis, 4 firms in stage 1, 3 firms in stage 2 and 9 firms in stage 3 were CRS efficient. In VRS, 10 firms in each stage were VRS efficient. In Scale efficiency analysis, 4 firms in stage 1, 16 firms in stage 2 and 9 firms in stage 3 were scale efficient. Only one IPO firm (number 3) showed 100 percent efficiency in all the three stages of CRS, VRS and Scale efficiency measures.

\section{Post IPO Sector-wise analysis}

The DEA results of stage 1 indicated that manufacturing sector CRS score was twice the score of financial and other sectors showing better efficiency. In VRS, the efficiency score of financial sector was greater than manufacturing and other sectors. In stage 2, both CRS and VRS analysis, manufacturing sector showed better efficiency than financial and other sectors. In contrast to the results of stage 1 and 2, the efficiency score under CRS of other sectors was observed to be greater than financial and manufacturing sectors. However, under VRS, financial sector showed better efficiency than manufacturing and other sectors and exceeded the score of 0.50 .

All these results suggest that none of the sectors was CRS and VRS efficient in all the three stages. The efficiency scores showed decreasing trend under CRS in all the three stages while comparing pre IPO with post IPO analysis in financial and other sectors. However, the results of manufacturing sector showed an increasing trend under CRS and VRS.

In sector-wise analysis, for CRS efficiency scores in stage 1, the financial services and personal goods sectors showed better efficiency score $(>0.5)$ than other sectors in the KSE. The sectors; Real Estate Investment \& Services, Media, Electricity, Automobile \& Parts, General Industrials, Banks and Support Services showed very low efficiency scores $(<0.2)$ under CRS. The VRS efficiency scores were observed to be higher than the efficiency scores of CRS in stage 1. For VRS efficiency score in stage 1, the Real Estate sector showed better performance than all other sectors showing an efficiency score of 0.81 .

In the marketability analysis of stage 2 , none of the sectors could meet the efficacy score of 0.5 under CRS except Oil and Gas Producer sector. However, in VRS, its efficiency score was at optimal level. All other sectors except Industrial Metals \& Mining showed efficiency score of less than 0.5 under VRS analysis of stage 2 . In the overall analysis of stage 3 , the efficiency scores were found to be higher than the efficiency scores in stage 1 and 2. In stage 3, only Oil and Gas Producer sector showed relatively good efficiency score under CRS and VRS.

In stage 1 , the efficiency scores for private and SOEs could not reach the efficiency score of 0.5 under CRS; however, under VRS, SOEs approached an efficiency score of 0.687 showing better efficiency than private enterprises. In stage 2, the efficiency scores remained less than 0.2 in CRS measure. However, in stage 2, under VRS, SOEs showed relative better efficiency than private. In stage 3 again SOEs showed relatively greater efficiency than private under CRS and VRS. The post IPO analysis showed that efficiency of SOEs was greater than the efficiency of private firms.

To sum up, the overall efficiency scores of IPO firms remained between 5 to 20 percent in all the three stages in post IPO. Even the efficiency scores are decreased in post IPO after one year. However, SOEs showed some better efficiency than private IPO firms. The efficiency scores in three different stages indicate that, after acquiring further resources of equity, assets and addition of employees, IPO firms did not improve their efficiency level after one year of IPOs.

\section{Post IPO efficiency: MPI Analysis}

To observe the efficiency of IPOs overtime, a time series analysis in DEA in the form of Malmquist Productivity Index (MPI) was used.

As in CRS and VRS analysis of efficiency scores, MPI is presented in five stages: efficiency change (effch), technical change (techch), pure efficiency change (pech), scale efficiency change (sech) and, total factor productivity change (tfch). In stage 1 , overall declining trend was observed in all change measures of MPI except the third one and found to be $0.778,0.974,1.027,0.831$ and 0.860 respectively from year 1 to year 3 after IPO. Similarly, in stage 2, efficiency change, technical change, pure efficiency change, scale efficiency change \& total factor productivity change were $0.686,0.658,0.825,0.821$ and 0.741 respectively. In stage 3 , the averages of efficiency change, technical change, pure efficiency change, scale efficiency change \& total factor productivity change were observed to be $0.898,0.949,0.880,0.992$ and 0.862 respectively.

The results were also consistent with other performance measure models; CARS, BHARs and Jensen's alphas measure by asset pricing models in which underperformance was observed after three years of IPOs. A positive technical efficiency change was observed in 34 out of 60 for stage 1, 22 out of 60 for stage 2 and 25 out of 60 for stage 3 for the first year of IPOs to third year of 
IPOs. It indicates an improvement in performance of IPOs in profit after tax and revenue by using inputs as assets, equity and number of employees for stage 1; improving the performance in EPS, MV using inputs as profit after tax, revenue and returns to investors for stage 2 and; improving the performance in EPS, MV and returns to investors by using inputs as assets, equity and number of employees for stage 3 . The results of positive technical efficiency indicate the overall managerial efficiency of IPOs after going public for three years.

A declining trend was observed in technological change in all three stages of IPOs after going public from year 1 to 3 . However, a positive technological change was observed in 25 out of 60 for stage 1, 11 out of 60 for both stages 2 and 3 for the first year of IPOs to third year of IPOs. This positive technological change in any IPO firm shifts production frontier upwards. Similarly, on average, a declining trend was also observed in pure technical efficiency in all three stages of IPOs after going public from year 1 to 3 . However, a positive pure technical efficiency was observed in 34 out of 60 for stage 1, 24 out of 60 for both stages 2 and 3 for the first year of IPOs to third year of IPOs.

As a result of MPI analysis, on an average, total productivity growth in all three stages showed a declining trend of IPOs after going public from year 1 to 3. Majority of IPO firms showed positive change in productivity growth in stage 1 showing better achievement. A positive total productivity growth was observed in 43 out of 60 for stage 1, 24 out of 60 for stage 2 and 25 out of 60 IPOs for stage 3 for first year to third year of IPOs.

The overall results of declining trend in total productivity growth of IPOs after three years period in KSE are in accordance with Alanzai (2010) and Yan and Zehong (2013) but contrary to Chen (2012) studies. Alanzai (2010) reported declining trend in total productivity growth of IPOs after going public. Yan and Zehong (2013) also reported inefficiencies of SOEs by using Malmquist Productivity Index for Chinese IPOs. On the other hand, Chen (2012) measured total factor productivity of banks and showed that technical efficiency of 21 banks improved by 106.22 percent, technological changes improved by 16.07 percent and the total factor productivity improved by 70.03 percent during 2006-11.

The Sector-wise analysis of MPI is presented in Table 3. The total productivity growth of financial and other sectors in all three stages from year 1 to 3 showed a declining trend. The manufacturing sector showed increase of 8.2 percent growth in stage 1 through improvement in profit after tax and revenue by using input as assets, equity and number of employees after the period of three years. The results are consistent with earlier study of Raheman et al. (2008) in which total productivity growth was observed to be 9 percent during 1998 to 2007 . However, his study was not about IPO firms. For stage 2 and 3, manufacturing sector also showed negative growth in total productivity after the period of three years of IPOs.

The results of negative technical efficiency indicate that overall managerial efficiency of IPOs decreased in manufacturing, financial and other sectors in stage 1 after going public for three years. However, an increase of 6.3 percent in financial and 1.2 percent in other sectors was observed in technological change in stage 1. Similarly, a positive technological change was observed in manufacturing, financial and other sectors in stage 1 showing shifting of production frontier upwards. In stage 2 , only manufacturing sector showed an increase of 3 percent in technological change.

In stage 1, panel B of Table 3 showed that managerial efficiency increased after three years in Industrial Transportation, Electricity, Chemicals, Automobile \& Parts, Media, Support Services, Construction and Materials, Personal Goods, Financial Services and Fixed Line Telecommunication sectors while decreased in Equity Investment Instruments, Software \& Computer Services, Banks, Oil \& Gas Producers, Real Estate Investment \& Services, Industrial Metals \& Mining and General Industrials sectors. Amongst these sectors, Industrial Transportation sector showed highest increase (22.8 percent) in managerial efficiency while General Industrial's sector showed lowest decrease in managerial efficiency.

Similarly, 8 out of 17 sectors including Real Estate Investment \& Services, Support Services, Industrial Metals \& Mining, Banks, Equity Investment Instruments, Media, Personal Goods, Construction \& Materials and Chemical, on average, showed an increasing trend under technological change in stage 1 of IPOs after going public from year 1 to 3 . Whereas, a negative technical change was observed in 9 out of 17 sectors for stage 1 with General Industrials sector at the bottom. In pure technical efficiency analysis, majority of the sectors showed positive trend while only 4 sectors (Construction \& Materials, Media, Industrial Metals \& Mining and Industrial Transportation) showed decreasing trend in stage 1 after three years. The MPI analysis showed that, on average, in stage 1 , total productivity growth in 10 sectors increased with Equity Investment Instruments sector at the top while in 7 sectors decreased with the Financial Services sector at the lowest.

In stage 2, panel B of Table 3 indicated that managerial efficiency increased after the period of three years in only six sectors while decreased in 11 sectors. Amongst these sectors, Real Estate Investment \& Services sector showed highest increase $(15.7$ percent $)$ in managerial efficiency.

In stage 2, none of the sectors showed increase in technological change after going public from year 1 to year 3. Besides, MPI analysis showed that, on average, total productivity growth increased in 6 out of 17 sectors with Fixed Line Telecommunication sector at top while it decreased in 9 sectors.

In stage 3, panel $\mathrm{B}$ of Table 3 indicated that managerial efficiency increased after three years in only six sectors while decreased in 11 sectors. Amongst these, General Industrial's sector showed highest increase in managerial efficiency of 20.3 percent. On the other hand, in stage 3, only two sectors showed increase in technological change after going public from year 1 to year 3. In addition, MPI analysis indicated, on average, total productivity growth in 6 out of 17 sectors with Support Services sector at the top while it decreased in 11 sectors. 
Table 3

Sector-wise analysis (MPI)

\begin{tabular}{|c|c|c|c|c|c|c|c|c|c|c|c|c|c|c|c|}
\hline \multirow[b]{2}{*}{ Sectors } & \multicolumn{5}{|c|}{ Stage 1} & \multicolumn{5}{|c|}{ Stage 2} & \multicolumn{5}{|c|}{ Stage 3} \\
\hline & effch & techch & Pech & sech & tfpch & effch & techch & Pech & Sech & tfpch & effch & techch & pech & Sech & Tfpch \\
\hline \multicolumn{16}{|c|}{ Panel A: Financial, Manufacturing \& Other Sectors } \\
\hline Financial Sector & 0.831 & 1.063 & 1.030 & 1.008 & 0.960 & 0.699 & 0.704 & 0.777 & 0.826 & 0.833 & 0.953 & 0.955 & 0.902 & 1.032 & 0.890 \\
\hline Manufacturing & 0.961 & 0.931 & 1.066 & 0.961 & 1.082 & 0.850 & 0.747 & 1.030 & 0.937 & 0.920 & 0.973 & 0.979 & 0.951 & 1.043 & 0.913 \\
\hline \multicolumn{16}{|c|}{ Panel B: Sector wise analysis } \\
\hline $\begin{array}{l}\text { Automobile And } \\
\text { Parts }\end{array}$ & 1.051 & 0.753 & 0.732 & 1.513 & 1.169 & 0.750 & 0.749 & 1.037 & 0.974 & 1.006 & 0.722 & 0.827 & 1.232 & 1.181 & 0.855 \\
\hline Banks & 1.073 & 0.887 & 1.079 & 0.934 & 0.892 & 0.690 & 0.805 & 0.842 & 0.908 & 0.761 & 0.936 & 0.990 & 0.757 & 1.071 & 1.003 \\
\hline Chemicals & 1.002 & 1.009 & 1.112 & 1.052 & 1.171 & 0.965 & 0.651 & 1.004 & 0.948 & 0.897 & 0.968 & 0.972 & 0.945 & 0.985 & 0.808 \\
\hline $\begin{array}{l}\text { Construction And } \\
\text { Materials }\end{array}$ & 0.764 & 0.891 & 1.092 & 1.062 & 1.095 & 1.033 & 0.721 & 1.052 & 0.786 & 0.904 & 1.105 & 0.999 & 0.804 & 1.080 & 0.937 \\
\hline Electricity & 0.974 & 1.069 & 0.906 & 1.140 & 1.212 & 0.799 & 0.975 & 1.142 & 0.984 & 1.039 & 0.780 & 0.877 & 0.676 & 0.717 & 1.124 \\
\hline $\begin{array}{l}\text { Equity Investment } \\
\text { Instruments }\end{array}$ & 0.666 & 1.336 & 1.028 & 0.926 & 0.949 & 0.652 & 0.673 & 0.747 & 0.810 & 0.890 & 1.049 & 0.947 & 1.030 & 1.074 & 0.701 \\
\hline Financial Services & 0.718 & 1.026 & 0.983 & 1.146 & 1.036 & 0.746 & 0.626 & 0.734 & 0.757 & 0.861 & 0.894 & 0.925 & 0.946 & 0.960 & 0.924 \\
\hline $\begin{array}{l}\text { Fixed Line } \\
\text { Telecommunication }\end{array}$ & 0.266 & 1.037 & 1.299 & 0.771 & 1.018 & 1.024 & 0.686 & 1.081 & 1.158 & 1.201 & 0.204 & 0.862 & 1.005 & 1.146 & 1.201 \\
\hline General Industrials & 1.092 & 0.753 & 1.208 & 0.923 & 0.132 & 1.019 & 0.514 & 1.099 & 1.000 & 1.000 & 1.255 & 0.872 & 1.049 & 1.000 & 0.812 \\
\hline $\begin{array}{l}\text { Industrial Metals } \\
\text { And Mining }\end{array}$ & 0.828 & 0.807 & 1.122 & 0.299 & 0.788 & 1.032 & 0.684 & 0.991 & 1.000 & 0.731 & 0.709 & 0.966 & 1.161 & 0.984 & 0.822 \\
\hline $\begin{array}{l}\text { Industrial } \\
\text { Transportation } \\
\end{array}$ & 0.974 & 1.070 & 1.000 & 0.005 & 1.228 & 0.800 & 0.750 & 0.978 & 1.028 & 1.000 & 0.643 & 0.850 & 1.201 & 1.014 & 0.380 \\
\hline Media & 1.033 & 0.845 & 1.157 & 1.226 & 1.127 & 0.972 & 0.527 & 0.762 & 0.596 & 0.545 & 1.240 & 0.891 & 0.876 & 0.937 & 0.774 \\
\hline $\begin{array}{l}\text { Oil And Gas } \\
\text { Producers } \\
\end{array}$ & 1.035 & 1.123 & 1.105 & 0.983 & 0.863 & 0.484 & 0.963 & 0.854 & 1.076 & 1.101 & 1.053 & 0.991 & 0.947 & 1.067 & 1.063 \\
\hline Personal Goods & 1.091 & 0.837 & 1.014 & 0.928 & 1.058 & 0.614 & 0.656 & 1.039 & 0.927 & 0.939 & 1.040 & 0.958 & 0.875 & 1.069 & 1.017 \\
\hline $\begin{array}{l}\text { Software \& } \\
\text { Computer Services }\end{array}$ & 1.046 & 1.214 & 0.877 & 0.141 & 0.948 & 0.646 & 0.828 & 1.101 & 1.020 & 1.161 & 0.287 & 1.203 & 1.130 & 1.000 & 0.727 \\
\hline Support Services & 1.027 & 0.699 & 1.185 & 1.063 & 1.110 & 1.023 & 0.337 & 0.618 & 0.558 & 0.160 & 0.969 & 0.964 & 1.000 & 0.878 & 1.269 \\
\hline \multicolumn{16}{|c|}{ Panel B: SOEs vs Private } \\
\hline SOEs & 0.915 & 1.071 & 1.055 & 0.945 & 1.056 & 0.663 & 0.965 & 0.945 & 0.868 & 0.882 & 0.954 & 0.970 & 0.878 & 1.043 & 0.926 \\
\hline Private & 0.904 & 0.990 & 1.052 & 0.972 & 0.994 & 0.814 & 0.654 & 0.890 & 0.881 & 0.876 & 0.941 & 0.951 & 0.928 & 1.010 & 0.905 \\
\hline
\end{tabular}

In general, sector-wise analysis showed mixed results of efficiency scores. Some sectors remained efficient in stage 1 , while others remained efficient in stage 2 and 3. However, efficiency of IPOs decreased in most sectors after three years. In marketability analysis, only six sectors showed efficiency under MPI.

The results are consistent with other models such as CARs, BHARs and Jensen's alphas (calculated by CAPM, three and four factor models), in which underperformance of IPOs were also observed after the period of three years. The results of these models are not presented but can be seen in author's referenced doctoral dissertation.

\section{Conclusion}

The results and discussion above indicate that the overall efficiency scores of IPO firms were dismal as the percentage of optimum level of IPO firms remained between 5 to 20 percent in all three stages for both pre and post IPO. In the analysis of broader categories of (private,
SOEs, manufacturing, financial and other services) sectors, the results of DEA model's three stages showed that neither of the sector was CRS efficient nor VRS efficient in pre and post IPO. However, SOEs showed slightly better efficiency than private IPO firms.

In pre IPO sector-wise analysis, none of the sectors showed efficiency score at optimum level except Software \& Computer Services sector showed its efficiency score in stage 3 close to optimal level under CRS. In VRS analysis, Oil \& Gas Producers, Electricity and Financial Services sectors also showed relatively good efficiency scores. Besides, Oil and Gas sector showed optimal level under VRS in stage 2 only. Therefore, pre IPO and after one year of IPO, no significant change was observed in the efficiency. These efficiency scores in three different stages suggest that, after acquiring additional resources of equity, assets and employees, IPO firms did not improve their efficiency level after one year of IPOs.

The results have indicated an overall declining trend in total productivity growth of IPOs after three years period 
in KSE. The manufacturing sector showed 8.2 percent growth in stage 1, while in detailed sector-wise analysis; mixed results were observed in five different measures of MPI. As mentioned earlier, the results of DEA and MPI are consistent with other performance measure models; CARs, BHARs and Jensen's alphas measure by asset pricing models in which underperformance was observed after three years of IPOs.

To observe the efficiency of IPOs through DEA, KSE has witnessed that the efficiency of SOEs was higher than private firms. It is recommended that government should encourage the SOEs to issue IPOs to improve their efficiency level.
The overall results suggest that, after acquiring additional resources of equity, assets and addition of employees, IPO firms did not improve their efficiency level and productivity growth after the period of three years of IPOs. For future research, the use of environmental variables may be included in the DEA approach. Further, in second phase of DEA, the efficiency scores should be taken as dependent variable to investigate the effect of different factors (such as valuation, liquidity and leverage of IPO firms) to find the reasons for underperformance and inefficiencies of IPOs on long run basis.

\section{References}

Alanazi, A.B., Liu, J., \& Forster. (2010). Saudi Arabian IPOs Productivity and Efficiency. Journal of Middle Eastern Finance and Economics, 6, 62-71.

Andries, A.M., Mehdian, S., \& Stoica, O. (2013). Impact of European Integration on Efficiency and Productivity Growth of Romanian Banks. Inzinerine Ekonomika- Engineering Economics, 24(3), $187-197$. http://dx.doi.org/10.5755/j01.ee.24.3.2922

Ataullah, A., \& Hang, Le. (2006). Economic reforms and bank efficiency in developing countries: the case of the Indian banking industry. Applied Financial Economics, 16, 653-663. http://dx.doi.org/10.1080/09603100500407440

Banker, R. D., Charnes A., \& Cooper W. W. (1984). Some Models for Estimating Technical and Scale Inefficiencies in Data Envelopment Analysis. Management Science, 30 (9), 1078-1092. http://dx.doi.org/10.1287/mnsc.30.9.1078

Banker, R. D., \& Thrall, R. M. (1992). Estimation of Returns to scale using Data Envelopment Analysis. European Journal of Operational Research, 62, 74-84. http://dx.doi.org/10.1016/0377-2217(92)90178-C

Berger, A. N., \& Mester, L. J. (2003). Explaining the Dramatic Changes in Performance of Us Banks: Technological Change, Deregulation, and Dynamic Changes in Competition. Journal of Financial Intermediation, 12, 57-95. http://dx.doi.org/10.1016/S1042-9573(02)00006-2

Brau, J. C., \& Fawcett, S. E. (2006). Evidence on what CFOs think about the IPO process: Practice, Theory and Managerial Applications. Journal of Applied Corporate Finance, 18(3), 107-117. http://dx.doi.org/10.1111/j.17456622.2006.00103.x

Carrico, C. S., Hogan, S. M., Dyson, R. G., \& Athanassopoulos, A.D. (1997). Data envelopment analysis and university selection. Journal of the Operational Research Society, 48, 1163-1177. http://dx.doi.org/10.2307/3010747

Caves, R. E. (1982). Multinational enterprise and economic analysis. Cambridge University Press, Cambridge, MA (1982)

Chanrnes, A., Cooper, W. W., \& Rhodes, W. E. (1978). Measuring the efficiency of Decision Making Units. European Journal of Operational Research, 2, 429-444. http://dx.doi.org/10.1016/0377-2217(78)90138-8

Chen, S. Y. (2012). Efficiency Analysis of Wealth Management IPO in Taiwan Banks. University of Taiwan.

Chen, Y., Cook W. D., \& Zhu J. (2009). Deriving the DEA Frontier for Two-Stage Processes. European Journal of Operational Research, 202, 138-42 http://dx.doi.org/10.1016/j.ejor.2009.05.012

Coelli, T. A. (1998). Guide to DEAP Version 2/1: A Data Envelopment Analysis Computer Program. Working Paper 96/08, CEPA, UNE, Australia.

Dyson, R. G., Allen, R., Camanho, A. S., Podinovski, V. V., Sarrico, C. S., \& Shale, E. A. (2001). Pitfalls and protocols in DEA, European Journal of Operational Research, 132, 245-259. http://dx.doi.org/10.1016/S0377-2217(00)00149-1

Edirisinghe, N. C. P., \& Zhang, X. (2008). Portfolio selection under DEA-based relative financial strength indicators: Case of US industries. Journal of the Operational Research Society, 59, 842-856. http://dx.doi.org/10.1057/palgrave. jors. 2602442

Edirisinghe, N. C. P., \& Zhang, X. (2010). Input / Output Selection in DEA under expert information, with Application to Financial Markets. European Journal of Operational Research, 207, 1669-1678. http://dx.doi.org/10.1016/ j.ejor.2010.06.027

Fama, E., \& French K. (1995). Size and Book-to-Market Factors in Earning and Return. Journal of Finance, 50, $131-155$. http://dx.doi.org/10.1111/j.1540-6261.1995.tb05169.x

Fama, E., \& French, K. (1993). Common risk factors in the returns of stocks and bonds. Journal of Financial Economics, 33, 3-56. http://dx.doi.org/10.1016/0304-405X(93)90023-5

Farrell, M. J. (1957). The measurement of productive efficiency. Journal of the Royal Statistical Society, $120(3), 253-282$. http://dx.doi.org/10.2307/2343100 
Muhammad Khalid Sohail, Muhammad S. Anjum. Efficiency Dynamics of Initial Public Offerings Using ...

Feroz, E. H., Kim, S., \& Raab, R. (2003). FINANCIAL STATEMENT ANALYSIS: A Data Envelopment Analysis Approach. Journal of the Operational Research Society, 54, 48-58. http://dx.doi.org/10.1057/palgrave.jors.2601475

Greg, N.G. (2006), Initial Public Offerings: An International Perspective. Butterworth Heinemann, USA, 2006.

Jenkins, L., \& Anderson, M. (2003). A multivariate statistical approach to reducing the number of variables in data envelopment analysis. European Journal of Operational Research, 147, 51-61. http://dx.doi.org/10.1016/S03772217(02)00243-6

Joro, T., \& Viitala, E. J. (2004). Weight-restricted DEA in action: From expert opinions to mathematical models. Journal of the Operational Research Society, 55, 814-821. http://dx.doi.org/10.1057/palgrave.jors.2601752

Kong, Nancy, Y. C., \& Tongzon, J. (2006). Estimating total factor productivity growth in Singapore at sectoral level using Data Envelopment Analysis. Applied Economics, (38), 2299-2314. http://dx.doi.org/10.1080/00036840500427544

Loughran, T., \& Ritter, J. R. (1995). The new issues puzzle. Journal of Finance, 50, $23-50$. http://dx.doi.org/10.1111/j.1540-6261.1995.tb05166.x

Luo, D., \& Shujie, Y. (2009). World Financial Crisis and the Rise of Chinese Commercial Banks. Research paper series, China and the World Economy, The University of Nottingham. http://dx.doi.org/10.2139/ssrn.1448521

Megginson, W. L., \& Netter, J. M., (2001). From state to market: a survey of empirical studies on privatization. Journal of Economic Literature, (XXXIX), 321-389. http://dx.doi.org/10.1257/jel.39.2.321

Miliotis, P. A. (1992). Data envelopment analysis applied to electricity distribution districts. Journal of the Operational Research Society, 43, 549-555. http://dx.doi.org/10.1057/jors.1992.80

Nunamaker, Thomas, R. (1985). Using Data Envelopment Analysis to Measure the Efficiency of Non-Profit Organization: A Critical Evaluation. Managerial and Decision Economics, 6(1), 50-58. http://dx.doi.org/10.1002/mde.4090060109

Raheman, A., Afza, T., Qayyum, A., \& Bodla, M. A. (2008). Estimating Total Factor Productivity and its Components: Evidence from Major Manufacturing Industries of Pakistan. Pakistan Development Review, 47(4), 677-694.

Ritter, J. (1991). The long-run performance of initial public offerings. Journal of Finance, 46, 3-28. http://dx.doi.org/10.1111/j.1540-6261.1991.tb03743.x

Shiu, A. (2002). Efficiency of Chinese Enterprise, The Journal of Productivity Analysis, 8(3), $255-267$. http://dx.doi.org/10.1023/A:1020690811711

Sohail, M. K., \& Nasr, M. (2007). Performance of Initial Public Offerings in Pakistan. International Review of Business Research Papers, 3(2), 420-441.

Sohail, M. K. (2015). Performance and Efficiency Dynamics of Initial Public Offerings in Pakistan. (Doctoral dissertation), Capital University of Science \& Technology, Islamabad.

Sufian, F., \& Kamarudin, F. (2014). Efficiency and Returns to Scale in the Bangladesh Banking Sector: Empirical Evidence from the Slack-Based DEA Method. Inzinerine Ekonomika-Engineering Economics, 25(5), 549-577. http://dx.doi.org/10.5755/j01.ee.25.5.5035

Vahid, S., \& Sowlati, T. (2007). Efficiency analysis of the Canadian wood - product manufacturing subsectors: A DEA approach. Forest Products Journal, 57(1/2), 71-77.

Wang, Jui-Chi. (2006). Corporate Performance efficiency investigated by Data Envelopment Analysis and Balanced Scorecard. The Journal of American Academy of Business, Cambridge, 9(2), 312-318.

Welch, I. (1989). Seasoned Offerings, Imitation Costs and the Underpricing of Initial Public Offerings. Journal of Finance, 421-449. http://dx.doi.org/10.1111/j.1540-6261.1989.tb05064.x

Worthington, A. C. (1999). Measuring Technical Efficiency in Australian Credit Unions. The Manchester School, 67(2), 231-248. http://dx.doi.org/10.1111/1467-9957.00144

Yan, G., \& Zehong, L. (2013). Empirical research on IPO financing efficiency of state-owned enterprises based on DEA. In Service Operations and Logistics, and Informatics (SOLI), IEEE International Conference, 73-78. http://dx.doi.org/10.1109/SOLI.2013.6611385

Zhu, J. (2000). Multi-factor performance measure model with an application to Fortune 500 companies. European Journal of Operational Research, 123 (1), 105-124. http://dx.doi.org/10.1016/S0377-2217(99)00096-X

The article has been reviewed.

Received in February, 2015; accepted in April, 2016. 